\title{
Evaluation of diquat for postemergence weed control in pumpkin (Cucurbita moschata)'
}

\author{
Luis Almodóvar-Vega, Manuel Díaz-Rivera, \\ and Nelson Semidey-Laracuente ${ }^{2}$
}

\begin{abstract}
In 1982, the bipyridilium herbicides diquat [6,7-dihydrodipyrido (1,2:2;i-c) pyrazineditum ion] at $0.56,1.12$ and $2.24 \mathrm{~kg}$ ai/ha, and paraquat [1,1-dimethyl-4,4' -bipyridinium ion] at $2.24 \mathrm{~kg}$ ai/ha were evaluated for postemergence control of weeds in pumpkin $\mathrm{cv}$. Borinquen (Cucurbita moschata (Duchesne) Poir). The experiment was established in Fraternidad clay soil, a Vertisol at the Lajas Substation, Agricultural Experiment Station.

No statistical dlfferences $(\mathrm{P}=0.05)$ in yield were detected among the hand-weeded plots $(25,580 \mathrm{~kg} / \mathrm{ha})$, diquat treated plots $(23,296 \mathrm{~kg} / \mathrm{ha})$, and paraquat treated plots $(27,341 \mathrm{~kg} / \mathrm{ha})$. Significant differences in plot yield were observed among paraquat $2.24 \mathrm{~kg}$ rate treatment, diquat at the lower rates, and the non-weeded plots. Yields were $0.56 \mathrm{~kg}$ diquat $(17,172 \mathrm{~kg} / \mathrm{ha}), 1.12 \mathrm{~kg}$ diquat $(19,551 \mathrm{~kg})$, and non weeded check $(10,243$ $\mathrm{kg} / \mathrm{ha})$.

All rates of herbicides provided $100 \%$ control of Ipomoea tillaceo L,; the higher rates also controlled over $85 \%$ Euphorbia heterophylla. Control of grass weeds was inefficient $10 \%$ or less) with diquat sprays 1 month after the second herbicide application. Nevertheless, diquat seems to be a promising candidate herbicide for postemergence weed control in pumpkin since it efficiently controlled broadleaf weeds with less toxic effect on applicators than paraquat.
\end{abstract}

\section{INTRODUCTION}

Pumpkin (Cucubita moschata) (Duchesne) Poir) is a vegetable crop of economic importance in Puerto Rico. In 1984-85, 18,829 t was produced with a farm value of $\$ 6.3$ million (5). At the same time $21,014 \mathrm{t}$ was imported to satisfy the local demand for this product.

Weeds interfere with pumpkin production. By competition and allelopathic effects they reduce crop yields and affect quality (6). Established planting distances for this crop permit exhuberant weed growth between hills (4). Mechanical cultivation to control weeds is only practical at the early growth stages of the crop cycle because the vines spread rapidly and can be damaged by farm machinery. A limited number of herbicides is registered in Puerto Rico for use in pumpkin (1). The perfor-

'Manuscript submitted to Editorial Board 2 September 1987.

${ }^{2}$ Researcher and Professor in Weed Science, former Graduate Student, and Assistant Researcher, respectively, Crop Protection Department, College of Agricultural Sciences, Mayagüez Campus, University of Puerto Rico. 
mance of bensulide, chloramben, DCPA and trifluralin was studied in pumpkin, cucumber and watermelon (7). Chloramben is recommended for preemergence weed control, but weeds like morning glory (Ipomoea tiliacea L.) are tolerant to it (2). There is the need to evaluate postemergence herbicides for this crop to complement preemergence herbicide treatments and mechanical cultivation for controlling late emerging weeds not previously controlled.

Paraquat herbicide is used in several vegetable crops as preplant or directed postemergence treatment to weeds. It is a toxic herbicide in the restricted use pesticide category. Diquat, on the other hand, not a restricted use herbicide, is about half as toxic to mammals as paraquat, and its efficacy in controlling weeds is similar to that of paraquat (3). For the above reasons diquat was evaluated as a possible candidate for weed control in pumpkin production.

\section{MATERIALS AND METHODS}

Pumpkin cv. Borinquen was sown February 11, 1982 at the Lajas substation farm in Fraternidad soil, a Vertisol. A randomized complete block design with four replications was employed. Each experimental plot measured $46.72 \mathrm{~m}^{2}$ with $1.83 \mathrm{~m}$ planting distances within and between rows. Plots consisted of 2 rows with a total of 10 plants.

Six treatments were evaluated in the trial: diquat at $0.56,1.12$ and $2.24 \mathrm{~kg}$ ai/ha; paraquat at $2.24 \mathrm{~kg}$ ai/ha; hand-weeded check (hoeing); and non-weeded check. The herbicide was applied with a hand-held compressed air sprayer equipped with tee jet 8004 nozzle tips set at $2 \mathrm{~kg} / \mathrm{cm}^{2}$ pressure. Weeds were sprayed 1 March and 15 March.

Overhead irrigation was applied immediately after sowing to induce germination, and thereafter water was applied by furrows according to crop needs until 3 weeks before the first picking. Plants were fertilized twice with $100 \mathrm{~kg} \mathrm{~N}, 100 \mathrm{~kg} \mathrm{P}_{2} 0_{5}$ and $80 \mathrm{~kg} \mathrm{~K} \mathrm{~K}_{2} \mathrm{O}$ per hectare at 10 and 40 days after seeding. Insects and diseases common to the crop were kept under preventive control with a mixture of diazinon and chlorathalonil at recommended rates applied 4 times during the growth span of the crop.

Fruits were picked three times, starting at 95 days after planting and thereafter every 8 days. Fruits were counted and weighed in each plot.

Percentage weed control was estimated by relative observations based on the coverage of the weed foliage. The visual ratings started 15 March, 2 weeks after the first herbicide treatment; the last rating was 15 April, 4 weeks after the second herbicide application. Non-weeded plots (with higher weed coverage) served as the basis for estimating percentage weed control in the other treatment plots. 
TABLE 1.-Total yield and number of pumpkins cv. Borinquen in the evaluation of herbicides (Lajas, 1982)

\begin{tabular}{lccr}
\hline Treatment & Rate & Yield $^{1}$ & Fruits $^{1}$ \\
\hline & $k g$ ai/ha & $k g / h a$ & No/ha \\
Diquat & 0.56 & $17,172 \mathrm{c}$ & $7,116 \mathrm{a}$ \\
Diquat & 1.12 & $19,551 \mathrm{bc}$ & $7,772 \mathrm{a}$ \\
Diquat & 2.24 & $23,296 \mathrm{abc}$ & $9,457 \mathrm{a}$ \\
Paraquat & 2.24 & $27,341 \mathrm{a}$ & $10,403 \mathrm{a}$ \\
Hand-weeded & - & $25,581 \mathrm{ab}$ & $10,065 \mathrm{a}$ \\
Non weeded & - & $10,243 \mathrm{~d}$ & $3,745 \mathrm{~b}$ \\
\hline
\end{tabular}

${ }^{2}$ Numbers in columns followed by the same letter do not differ significantly at the $\mathrm{P}=0.05$ level (Duncan's multiple range test).

\section{RESULTS AND DISCUSSION}

\section{Yield and Fruit Number}

The highest yield was obtained in plots treated with paraquat at the rate of $2.24 \mathrm{~kg}$ ai/ha; next highest was from the hand-weeded plots; third highest yield was from plots treated with diquat at the rate of $2.24 \mathrm{~kg}$ ai/ha plots (table 1). No statistical differences in yields were observed among these treatments. Other diquat treated plots were lower yielders but yielded significantly higher than the weedy plots. In number of fruits per area the lowest yielders were the weedy plots, significantly inferior to other treatments. No statistical differences in fruit number were detected among the paraquat, diquat and hand-weeded plots, although fewer fruits were produced in the lower rate diquat plots.

According to the above results, weed interference may reduce pumpkin yields and the number of fruits about $50 \%$. Diquat proved to be a good postemergence herbicide for weed control in pumpkin, an alternative to hand weeding to lower production costs.

\section{Weed Control}

Prevalent broadleaf weeds in the experimental area were spurge [Euphorbia heterophyll (L)] and morning glory [Ipomoea tiliacea (Willd.) Choisy]; grass weeds were johnson grass [Sorghum halepense (L.)], jungle rice [Echinochloa colonum (L.)], and red sprangletop [Leptochloa filiformis (Lam.) Beauv.]. Tables 2, 3 and 4 present percentage weed control by visual ratings for three dates.

Two weeks after the first herbicide application, $E$. heterophylla and I. tiliacea were excellently controlled with one rate of paraquat and diquat at all rates. The lower and medium rates of diquat did not control grass weeds efficiently but the higher rate of diquat controlled $89 \%$ of the grasses; paraquat controlled $97 \%$ of the grass weeds (table 2 ). 
TABLE 2.-Pereentage weed control based on visual ratings 2 weeks following first herbicide application (March 15, 1982)

\begin{tabular}{|c|c|c|c|}
\hline \multirow[b]{2}{*}{ Treatment } & \multirow[b]{2}{*}{ Rate } & \multicolumn{2}{|c|}{ Weed control ${ }^{1}$} \\
\hline & & $\overline{\text { Grasses }}$ & Broadleaves \\
\hline & kg ai/ha & \multicolumn{2}{|c|}{$\%$} \\
\hline Diquat & 0.56 & $37 \mathrm{c}$ & $99 a$ \\
\hline Diquat & 1.12 & $61 \mathrm{~b}$ & $99 a$ \\
\hline Diquat & 2.24 & $89 a$ & $97 \mathrm{a}$ \\
\hline Paraquat & 2.24 & $97 \mathrm{a}$ & 97 a \\
\hline Hand-weeded & $100 a$ & $100 a$ & \\
\hline Non weeded & - & $0 d$ & $0 \mathrm{~b}$ \\
\hline
\end{tabular}

${ }^{1}$ See table 1.

Two weeks after a second herbicide application the same trend in weed control was observed for the different treatments, but with a slight reduction in herbicide efficacy (table 3). Four weeks after a second herbicide application, noxious grasses were tolerant to all diquat treatments with $10 \%$ control or less (table 4 ). With diquat at the rates of 0.56 and $1.12 \mathrm{~kg}$ ai/ha $I$. tiliacea was effectively controlled, but $E$. heterophylla was poorly controlled ( $35 \%$ or less). All grass and broadleaf weeds were effectively controlled with paraquat at $2.24 \mathrm{~kg}$ ai/ha.

Diquat controls broadleaf weeds efficiently and may be used for directed postemergence control of broadleaf weeds in pumpkin. If preemergence chloramben is applied and I. tiliacea is becoming a problem because of its tolerance to the herbicide, a postemergence application of diquat may solve the problem.

The higher rate of diquat also provided fair to good control of total weeds and resulted in good pumpkin yields. Diquat is a possible candidate herbicide for postemergence control of weeds in pumpkin where there is need for chemical control with less risk of toxic effect.

TABLE 3.-Percentage weed control based on visual ratings 2 weeks after a second herbicide application (March 31,1982 )

\begin{tabular}{lccr}
\hline \multirow{2}{*}{ Treatment } & Rate & \multicolumn{2}{c}{ Weed control ${ }^{1}$} \\
\cline { 4 - 5 } & Grais & & $\%$ \\
Diquat & 0.56 & $37 \mathrm{c}$ & $99 \mathrm{a}$ \\
Diquat & 1.12 & $61 \mathrm{~b}$ & $99 \mathrm{a}$ \\
Diquat & 2.24 & $89 \mathrm{a}$ & $97 \mathrm{a}$ \\
Paraquat & 2.24 & $97 \mathrm{a}$ & $97 \mathrm{a}$ \\
Hand-weeded & - & $100 \mathrm{a}$ & $100 \mathrm{a}$ \\
Non weeded & - & $0 \mathrm{~d}$ & $0 \mathrm{~b}$ \\
\hline
\end{tabular}

${ }^{1}$ See table 1. 
TABLE 4.-Percentage weed control based on visual ratings 4 weeks following a second herbicide application (April 5, 1982)

\begin{tabular}{lcccc}
\hline & & \multicolumn{3}{c}{ Weed control } \\
\cline { 3 - 5 } \multicolumn{1}{c}{ Treatment } & Rate & Grasses & B. heterophylla & I. titiacea \\
\cline { 4 - 5 } & kgailha & & & $\%$ \\
Diquat & 0.56 & $4 \mathrm{bc}$ & $20 \mathrm{~d}$ & $100 \mathrm{a}$ \\
Diquat & 1.12 & $10 \mathrm{~b}$ & $35 \mathrm{c}$ & $100 \mathrm{a}$ \\
Diquat & 2.24 & $10 \mathrm{~b}$ & $85 \mathrm{~b}$ & $100 \mathrm{a}$ \\
Paraquat & 2.24 & $96 \mathrm{a}$ & $88 \mathrm{a}$ & $100 \mathrm{a}$ \\
Hand-weeded & - & $100 \mathrm{a}$ & $100 \mathrm{a}$ & $0 \mathrm{~b}$ \\
Non weeded & - & $0 \mathrm{c}$ & $0 \mathrm{e}$ & $0 \mathrm{~b}$ \\
\hline
\end{tabular}

${ }^{1}$ See table 1 .

\section{RESUMEN}

Diquat como yerbicida posemergente en calabaza

En 1982 los herbicidas diquat a razón de $0.56,1.12$ y $2.24 \mathrm{~kg}$ p.a./ha. $y$ paraquat a razón de $2.24 \mathrm{~kg}$, p.a./ha. se evaluaron para el desbroce de malezas en aplicaciones posemergentes dirigidas en el cultivo de la calabaza (Cucurbita moschata) var. Borinquen. El experimento se estableció en un suelo Vertisol, Fraternidad arcilloso, en la Subestación Experimental Agrícola de Lajas.

Se obtuvieron excelentes rendimientos de calabaza con dos aplicaciones de diquat o paraquat a razón de $2.24 \mathrm{~kg}$. p.a./ha. a los 17 y 32 días después de sembrar. No se observaron diferencias significantivas $(P=0.05)$ en rendimiento entre las parcelas desyerbadas con azada $(25,580 \mathrm{~kg} . / \mathrm{ha}$.$) , las$ tratadas con diquat $(23,296 \mathrm{~kg}$./ha.) y las tratadas con paraquat $(27,341$ $\mathrm{kg}$./ha.) a razón de $2.24 \mathrm{~kg}$. p.a./ha. de cada herbicida. Hubo diferencias significativas entre las parcelas tratadas con las dosis altas y las tratadas con las más bajas de diquał y las parcelas testigo sin desyerbar $(10,243$ kg./ha.).

Ambos herbicidas en las concentraciones aplicadas fueron eficaces contra el bejuco de puerco (Ipomoea tiliacea L.) en un 100\%. Las concentraciones de $2.24 \mathrm{~kg} . / \mathrm{ha}$. de los herbicidas también lo fueron con la lechecilla (Euphorbia heterophyla L.) en más de $85 \%$. El desbroce de gramíneas fue ineficaz ( $10 \%$ o menos) al mes de una segunda aplicación de los herbicidas posemergentes. Sin embargo, diquat parece ser un herbicida prometedor en el cultivo de calabazas ya que es muy tóxico para las malezas de hoja ancha, pero menos tóxico que paraquat para quienes lo usen.

\section{LITERATURE CITED}

1. Acín, N., O'Farrill, H. and, Montalvo Zapata. R., 1984. Plaguicidas con permiso de uso para hortalizas en Puerto Rico. Plaguicidas al Día. Esta Exp. Agric./Agric. Ext. Serv. Publ. Univ. P. R., Mayagüez Campus.

2. Almodóvar-Vega L. and Vélez-Báez, 1980. Evaluation of metribuzin, prometryn, and chloramben for weed control on pigeon peas (Cajanus cajan (L.) Millsp.) J. Agric. Univ. P.R. 64 (1): 29-32. 
3. Anonymous, 1983. Herbicide Handbook-5th Ed. Weed Science Society of America. Champaign Illinois.

4. - 1979. Conjunto Technológico para la Producción de Hortalizas, Publ. 102. esta Exp. Agric. Univ. P. R., Río Piedras.

5. — , 1984-85. Informe de Estadísticas Agrícolas. Dep. Agric., Santuree, Puerto Rico.

6. Guzmán Pérez, Carmen D., 1986. Períodos críticos de competición y efectos alelopáticos de algunas malezas en calabaza y berenjena. M. S. Thesis. Univ. P. R., Mayagüez Campus.

7. Semidey, N., L. Almodóvar and I. Reyes, 1986. Herbicide evaluation in three cucurbits, J. Agric. Univ. P. R. 70 (2):85-90. 